\title{
Acute toxicity evaluation of Tricyclozole 75\% WP on earthworms Eisenia fetida
}

\author{
Vijayalakshmi Aalaysam $^{\star 1}$, \\ Venkata Reddy Bandugula ${ }^{2}$ \\ ${ }^{1}$ Department of Marine Living Resources, \\ HPCL Colony, Paanduranga Puram, \\ Visakhapatnam, Andhra University, \\ Andhra Pradesh 530003, India \\ ${ }^{2}$ Department of Animal Science, \\ Chonbuk National University, \\ 567 Baekje-daero, deokjin-gu, \\ Jeonju-sin, Jeollabuk-do 54896, \\ Republic of Korea
}

\begin{abstract}
Earthworms (Eisenia foetida) were exposed to Tricyclozole $75 \%$ WP pesticides in an acute earthworm toxicity test as per OECD guideline 207. Four replicates of ten clitellated adult earthworms each were exposed to the concentrations of $31.25,62.5$, $125,250,500$, and $1000 \mathrm{mg} / \mathrm{kg}$ dry soil. The control artificial soil with acetone and quartz sand had four replicates, with ten earthworms in each replicate. Earthworms were assessed for behavioural effects at 0,7 , and 14 days of exposure, mortality after 7 and 14 days of exposure, and the earthworm biomass was assessed on day 0 and on day 14 . The results of the study revealed acute toxicity of Tricyclozole 75\% WP to the earthworm Eisenia fetida in artificial soil
\end{abstract}

Keywords: Tricyclazole $75 \%$ WP, Eisenia fetida, mortality, biomass

\section{INTRODUCTION}

Earthworms are important organisms that play a vital role in the development of the nutrient content in the soil. For the earthworm, suitable conditions for living in soil is a $\mathrm{pH}$ close to $7.0 \pm 0.5$. Earthworms act as carriers of nutrients between the soil and the crops. Most of Indian economy rests on agriculture, nearly $70 \%$ of the total population depends on it. To eradicate insects and increase the productivity of the crops, farmers spray pesticides. When pesticides are used appropriately, they are eco-friendly. Nowadays, however, the use of pesticides is on the rise and pesticides remain as traces in the soil. This affects the natural living organisms in soils and also has an adverse affect on the human health. Pesticide pollution is the main environmental issue for rice-growing areas, because pesticides in rice fields enter the open environment easily and may affect the quality of

* Corresponding author. E-mail: vijjumlr@gmail.com such resources as groundwater and surface water (Mohammadian et al., 2015).

Tricyclazole fungicide products are marketed both as granules and wettable powders. Most formulations contain 750 grams of active ingredient per kilogram of product and the product is referred to as Tricyclazole 75\% WP. Tricyclazole is slightly soluble in water and moderately toxic to aquatic organisms on an acute basis. Tricyclazole is stable at an ambient temperature and it will degrade slowly under environmental conditions. Tricyclazole ((5-methyl-1,2,4-triazolo[3,4b]benzothiazole) is a common fungicide used to proctect rice crops (Phong Kh T et al., 2009; Habibzadeh F et al., 2012; Young Deuk Lee et al., 1998). This substance has a relatively high retention in soil and water, and contact with it can lead to health problems (Fattahi et al., 2015; Padovani et al., 2006; Qiu et al., 2013). Studies have shown that this toxin and its metabolites cause more damage in aquatic organisms than to mammals (Jeong et al., 2012; WHO, 2004). 
Eisenia fetida is the standard test organism used in terrestrial ecotoxicology, because it can be easily bred on a variety of organic wastes with short generation times (Shahla Yasmin et al., 2010; ISO, 1993; ISO, 1998; OECD, 1984). Its susceptibility to chemicals resembles that of true soil organisms. Sensitivity tests of multiple earthworm species have revealed that Eisenia fetida is comparatively less sensitive (OECD, 2004; Ma et al., 1993; Kula, 1995). Although earthworm species vary in their tolerance, reports have shown a decline in earthworm populations in response to large amounts of organic chemical deposition (Fitzgerald et al., 1996; Bayer et al., 1982).

The current research was conducted in order to evaluate the acute toxicity of Tricyclozole $75 \%$ WP to earthworms after 7 and 14 days of exposure and to estimate NOEC (no observed effect concentration) and $\mathrm{LC}_{50}$ of the test item to Eisenia fetida.

\section{MATERIALS AND METHODS}

\section{Materials}

Tricyclozole 75\% WP with the expiry date of two years from the date of manufacturing was purchased from market having.

2-chloroacetamide was purchased from Sigma Aldrich. The $\mathrm{LC}_{50}$ of the 2-chloroacetamide is determined twice in a year as a means of assuring that the laboratory test conditions are adequate and have not changed significantly.

\section{Biological system}

Earthworms (Eisenia fetida) were procured from Vanishri Agrochem Pvt. Ltd, Pune, India. Earthworms (Eisenia fetida) of 3-4 months of age with biomass of 300-600 mg/worm remained in the breeding medium (50:50 ratio of cow manure and coco peat) at $20 \pm 2{ }^{\circ} \mathrm{C}$, light regime of $16 \mathrm{~h}$ light $/ 8 \mathrm{~h}$ dark, and light intensity of 400 to 800 lux. Prior to use, the earthworms were observed for obvious physical or distinct behavioural changes, if any. The earthworms were acclimatized for one day in the artificial soil under environmental test conditions.

\section{Preparation of the artificial soil}

The artificial soil was prepared using dry constituents, viz., 10\% Sphagnum-peat (air-dried and finely ground with no visible plant remains), 20\% kaolin clay (kaolinite content $>30 \%$ ), approximately $69 \%$ fine quartz sand ( $>50 \%$ of the particles ranged between 50 to 200 microns). The above ingredients were mixed thoroughly using homogenizer for about 20 minutes. The remaining $1 \%$ of sand was added during the test substance application. Before initiating the study, the soil was prepared and stored until use in an airtight plastic container.

Maximum Water Holding Capacity (MWHC): Water content of the study was based on Maximum Water Holding Capacity of the artificial soil. A double-ended open glass tube $(10.0 \times 5.0 \mathrm{~cm})$ with a cotton cloth covering one of its ends was weighed ( $\mathrm{T}$ ) and artificial soil (approximately $100 \mathrm{~g}$ ) was filled compactly through the open end to a depth of 5-7 $\mathrm{cm}$ of the tube. The tube was then gradually immersed in water contained in a wide-mouth bowl, until the water level was just above the top of the soil. This setup was kept undisturbed for $3 \mathrm{~h}$. The soil sample was then allowed to drain the excess water for $2 \mathrm{~h}$ by placing the tube in a bed of fine wet sand contained within a covered vessel (to prevent drying). After this period has lapsed, the sample was weighed (S) and dried at $105^{\circ} \mathrm{C}$ for $3 \mathrm{~h}$ using a hot air oven.

The sample was weighed after drying (D) and the maximum water holding capacity of the artificial soil was calculated as follows:

$$
\text { MWHC } \%(\text { dry mass })=\frac{S-T-D}{D} \times 100
$$

where $S=$ water saturated soil + mass of the tube + mass of the cotton cloth $(\mathrm{g})$

$T=$ Tare (mass of tube + cotton cloth) in $g$

$D=$ Dry mass of the soil (g)

During test item application, the soil was moistened with de-ionised water corresponding to approximately $52.90 \%$, maximum water holding capacity $(66.16 \%)$ of the artificial soil. The moisture content of the artificial soil was determined at the start (day 0 , after test item 
application) and at the end (day 14) of the experiment by the following procedure: a known quantity of soil was uniformly spread in a Petri dish and the initial weight of the soil was noted. The soil was dried by placing the Petri dish in a hot air oven at $105{ }^{\circ} \mathrm{C}$ for 3 hours. Final weight of the soil after drying was recorded and the moisture content was calculated using the following formula (oven drying method):

Moisture content (dry weight basic) $=$

$$
\frac{I-F}{F} \times 100
$$

$I=$ Initial weight of the soil before placing in the hot air oven

$F=$ Final weight of the soil after drying

The moisture content was in the range of $33.73 \%$ to $34.95 \%$ at the test start (day 0), and $35.50 \%$ to $35.83 \%$ at the end of the test (day 14 ). The $\mathrm{pH}$ of the artificial soil was determined at the start (after test item application) and end of the experiment. It was in the range of 7.03 to 7.94 at the test start (day 0), and 6.48 to 7.63 at the end of the test (day 14). The complete data is presented in Table 1.

\section{Test conditions}

The controlled environment room maintained at $19.8-22.0^{\circ} \mathrm{C}$, at continued light intensity of 444-635 lux on the test container. Test conditions (temperature and light intensity) and test conditions for the soil ( $\mathrm{pH}$ and water content) were recorded with suitable calibrated instruments at start and at the end of the test.

\section{Test conduct}

Healthy earthworms with well-developed clitellum were selected, washed with tap water, blotted carefully with filter paper, weighed as a group of ten worms, and then released onto the surface of the treated artificial soil. The soil water content of each container was checked periodically by weighing, and water was added. Therefore the loss of soil moisture was kept within $10 \%$ of the initial soil moisture content for a period of 14 days.

Table 1 . The $\mathbf{p H}$ and moisture content during the course of the test

\begin{tabular}{|c|c|c|c|c|c|c|c|c|c|}
\hline \multirow{3}{*}{$\begin{array}{l}\text { Treatments } \\
\text { (mg/kg dry } \\
\text { soil) }\end{array}$} & \multicolumn{4}{|c|}{ Range finding experiment ${ }^{1}$} & \multirow{3}{*}{$\begin{array}{l}\text { Treatments } \\
\text { (mg/kg dry } \\
\text { soil) }\end{array}$} & \multicolumn{4}{|c|}{ Main experiment $^{2}$} \\
\hline & \multicolumn{2}{|c|}{$\mathrm{pH}$} & \multicolumn{2}{|c|}{$\%$ moisture content } & & \multicolumn{2}{|c|}{$\mathrm{pH}$} & \multicolumn{2}{|c|}{$\%$ moisture content } \\
\hline & $\begin{array}{c}\text { Test } \\
\text { start } \\
\text { (day 0) }\end{array}$ & $\begin{array}{l}\text { Test end } \\
\text { (day 14) }\end{array}$ & $\begin{array}{c}\text { Test } \\
\text { start } \\
\text { (day 0) }\end{array}$ & $\begin{array}{l}\text { Test end } \\
\text { (day 14) }\end{array}$ & & $\begin{array}{c}\text { Test } \\
\text { start } \\
\text { (day 0) }\end{array}$ & $\begin{array}{l}\text { Test end } \\
\text { (day 14) }\end{array}$ & $\begin{array}{c}\text { Test start } \\
\text { (day 0) }\end{array}$ & $\begin{array}{l}\text { Test end } \\
\text { (day 14) }\end{array}$ \\
\hline $\begin{array}{c}\text { Control } \\
\text { (acetone + } \\
\text { quartz sand) }\end{array}$ & 6.49 & 7.35 & 36.09 & 35.03 & $\begin{array}{l}\text { Control (ac- } \\
\text { etone + quartz } \\
\text { sand) }\end{array}$ & 7.03 & 6.48 & 33.73 & 35.64 \\
\hline 10 & 7.16 & 7.96 & 36.70 & 35.04 & 31.25 & 7.54 & 7.24 & 34.95 & 35.56 \\
\hline 33 & 7.15 & 8.04 & 38.10 & 35.58 & 62.5 & 7.66 & 7.26 & 34.71 & 35.80 \\
\hline 100 & 6.99 & 8.07 & 35.72 & 35.03 & 125 & 7.49 & 7.25 & 34.36 & 35.50 \\
\hline 333 & 7.06 & 8.01 & 34.91 & 34.63 & 250 & 7.94 & 7.63 & 34.74 & 35.83 \\
\hline 667 & 7.00 & 8.19 & 35.54 & 34.00 & 500 & 7.73 & 7.51 & 34.73 & 35.67 \\
\hline 1000 & 6.94 & 8.14 & 35.27 & 35.26 & 1000 & 7.62 & 7.62 & 34.95 & 35.55 \\
\hline Min. & 6.49 & 7.35 & 34.91 & 34.00 & Min. & 7.03 & 6.48 & 33.73 & 35.50 \\
\hline Max. & 7.16 & 8.19 & 38.10 & 35.58 & Max. & 7.94 & 7.63 & 34.95 & 35.83 \\
\hline
\end{tabular}

${ }^{1}$ Non replicated

${ }^{2}$ Representative samples from 4 replicates 


\section{Experimental procedure}

Before the start of the experiment, approximately 3-4-month-old healthy (active movement and shiny skin), clitellated earthworms were collected from the breeding box and acclimatized for one day in the artificial soil. The earthworms may typically be exposed to agricultural pesticides and their soil degradates present within the soil profile.

For each test, $550 \mathrm{~g}$ artificial soil (dry weight) was filled into each glass container. The artificial soil was moistened with approximately half of the final water content one day before the application. On the day of the experiment, the testitem was dissolved in acetone (maximum of $10 \mathrm{ml} / \mathrm{kg}$ dry soil) and applied to quartz sand (10 g of quartz sand/kg dry soil) in a Petri dish and left uncovered to enable complete evaporation of solvent from sand. Thus prepared, the test item (Tricyclozole 75\% WP) and quartz sand mixture was blended thoroughly with the artificial soil, along with the remaining water, using a laboratory mixer. Control received acetone alone, without the test item. The soil for each concentration was treated in two batches and each batch was further divided into two replicates, thus there were four replicates altogether at each concentration level. The wet weight of the soil was documented at the beginning of the test. The test medium was ventilated before use.

Ten earthworms, which have been acclimatized for a day in the artificial soil, were washed, blotted carefully, and released randomly into the test medium. The containers were covered with perforated plastic lids to prevent the test medium from drying. Non-replicated range finding study was conducted with 10 worms/ treatment with $10,33,100,333,667$, and $1000 \mathrm{mg} / \mathrm{kg}$ dry soil to arrive at accurate concentrations for the definitive test (Table 2).

Based on the mortality and biomass change from the range finding test, the following concentration viz., $31.25,62.5,125,250,500$, and $1000 \mathrm{mg} / \mathrm{kg}$ dry soil were selected in order to demonstrate that the $\mathrm{LC}_{50}$ of the test item is more than $1000 \mathrm{mg} / \mathrm{kg}$ dry soil. The concentrations are nominal amounts. Deviation to the target concentration was less than $10 \%$ (Table 3).

Application order: control (acetone + quartz sand) and the test item (from low to high concentrations).

\section{Parameters observed}

The artificial soil was emptied from the beaker and searched for earthworms on days 7 and 14 after test item application. The number of live and dead earthworms in each replicate was assessed on each of these days. Earthworms were considered dead if they failed to respond to gentle stimulation. Due to rapid decomposition under test conditions, missing earthworms were also considered dead.

The number of worms that did not burrow into the soil, if any, was recorded as behavioural abnormalities at the test start (day 0). Also, other behavioural abnormalities and toxic symptoms, if any, were observed during each mortality assessment. After the mortality check on day 7 , the live earthworms and

Table 2. Preparation of test item concentrations for the range finding test

\begin{tabular}{c|cc}
\hline $\begin{array}{c}\text { Amount of test item weighed } \\
{[\mathbf{m g} / \mathbf{0 . 5 5} \mathbf{~ k g ~ d r y ~ s o i l ] ~}}\end{array}$ & $\begin{array}{c}\text { Resulting concentration } \\
{[\mathrm{mg} / \mathrm{kg} \text { dry soil }]}\end{array}$ & $\begin{array}{c}\text { Quantity of deionised water } \\
\text { added/0.55 kg } \\
\text { Dry soil (g) }\end{array}$ \\
\hline 5.7 & 10.36 & 193 \\
\hline 18.5 & 33.64 & 193 \\
\hline 55.3 & 100.55 & 193 \\
\hline 183.4 & 333.45 & 193 \\
\hline 367.0 & 667.27 & 193 \\
\hline 550.1 & 1000.18 &
\end{tabular}


Table 3. Preparation of test item concentrations for the main test

\begin{tabular}{c|c|c|c}
\hline \multicolumn{2}{c|}{$\begin{array}{c}\text { Amount of test item weighed } \\
{[\mathbf{m g} / \mathbf{1 . 1} \mathbf{~ k g} \text { dry soil] }}\end{array}$} & \multirow{2}{*}{$\begin{array}{c}\text { Resulting concentration } \\
{[\mathbf{m g} / \mathbf{k g} \text { dry soil }]}\end{array}$} & $\begin{array}{c}\text { Quantity of deionised water } \\
\text { added/1.1 kg } \\
\text { dry soil (g) }\end{array}$ \\
\cline { 1 - 2 } Batch I & Batch II & 31.5 & 386 \\
\hline 34.9 & 34.4 & 62.6 & 386 \\
\hline 69.0 & 68.8 & 125.3 & 386 \\
\hline 137.7 & 138.0 & 250.5 & 386 \\
\hline 275.1 & 276.1 & 501.0 & 386 \\
\hline 551.1 & 551.0 & 1001.8 & 386 \\
\hline 1100.4 & 1103.5 & & \\
\hline
\end{tabular}

the artificial soil were returned to the respective test containers. Healthy earthworms with well-developed clitellum were selected, washed with tap water, blotted carefully with filter paper, weighed as a group of 10 worms and then released on the surface of the treated artificial soil.

At the start (day 0) and the end (day 14) of the test, the soil water content and $\mathrm{pH}$ in each test concentration and control (representative samples from each treatment group) were determined.

\section{Observations}

Since the observed mortality was less than $50 \%(2.5 \%$ in $1000 \mathrm{mg} / \mathrm{kg}$ dry soil, the high- est concentration tested), $\mathrm{LC}_{50}$ analysis was not performed. The $\mathrm{LC}_{50}$ was estimated to be more than the highest concentration tested. Fisher's exact test was performed to estimate the NOEC (no observed effect concentration) related to mortality, using TOXSTAT version 3.5 software.

The biomass changes of the treated and untreated series were analysed for homogeneity and normality using Bartlett's and Kolmogorov tests, respectively. Since the data was homogenous and normally distributed, Dunnett's test was performed (multiple comparison, one sided) to estimate the NOEC using TOXSTAT version 3.5 software (Table 4 ).

Table 4. Results of the test item with the reference item, 2-Chloroacetamide

\begin{tabular}{|c|c|c|c|c|c|c|}
\hline \multirow{2}{*}{ Treatment Group } & \multirow{2}{*}{$\begin{array}{c}\text { Control } \\
\text { (deionised } \\
\text { water) }\end{array}$} & \multicolumn{5}{|c|}{ 2-Chloroacetamide [mg/kg dry soil wt.] } \\
\hline & & 6 & 12 & 24 & 48 & 96 \\
\hline Mortality after 14 days $(\%)^{1}$ & 0 & $0^{\text {n.s }}$ & $0^{\text {n.s }}$ & $0^{\text {n.s }}$ & $100^{*}$ & $100^{*}$ \\
\hline Biomass change after 14 days $(\%)^{2}$ & -6.38 & $-0.61^{\text {n.s }}$ & $-3.26^{\mathrm{n} . \mathrm{s}}$ & $-6.02^{\mathrm{n} . \mathrm{s}}$ & $-100^{*}$ & $-100^{*}$ \\
\hline 14 day $\mathrm{LC}_{50}$ & \multicolumn{6}{|c|}{$36 \mathrm{mg} / \mathrm{kg}$ dry soil } \\
\hline $\begin{array}{l}\text { Fiducial limits } \\
\text { (95\% confidence) }\end{array}$ & \multicolumn{6}{|c|}{ Could not be determined } \\
\hline $\begin{array}{l}\text { LOEC related to mortality and } \\
\text { biomass }\end{array}$ & \multicolumn{6}{|c|}{$48 \mathrm{mg} / \mathrm{kg}$ dry soil } \\
\hline $\begin{array}{l}\text { NOEC related to mortality and } \\
\text { biomass }\end{array}$ & \multicolumn{6}{|c|}{$24 \mathrm{mg} / \mathrm{kg}$ dry soil } \\
\hline
\end{tabular}

n.s. $=$ no statistically significant differences compared to the control

* = statistically significant differences compared to the control

${ }^{1}$ Fisher's exact test, $\alpha=0.05 ;{ }^{2}$ Dunnett's test, $\alpha=0.05$ 


\section{RESULTS AND DISCUSSIONS}

\section{Range finding test}

Mortality

Fourteen days after exposure to the test item, no mortality was observed in any of the treatments on day 7 . However, $10 \%$ mortality was observed in test item treatment, $667 \mathrm{mg} / \mathrm{kg}$ dry soil on day 14. The details are presented in Table 5

\section{Biomass}

The biomass changes of the earthworms in the test item treatment ranged between $-42.07 \%$ (667 mg/kg dry soil) and $-7.70 \%$ (10 mg/kg dry

Table 5. Results of the range finding study

\begin{tabular}{|c|c|c|c|c|c|c|c|c|c|}
\hline \multirow{2}{*}{ No. } & \multirow{2}{*}{$\begin{array}{l}\text { Treatments } \\
\text { (mg/kg dry } \\
\text { soil) }\end{array}$} & \multicolumn{3}{|c|}{$\begin{array}{c}\text { Behavioural abnor- } \\
\text { malities [\%] }\end{array}$} & \multicolumn{3}{|c|}{ Biomass (mg/worm) ${ }^{\star}$} & \multicolumn{2}{|c|}{ Mortality (\%) } \\
\hline & & day 0 & day 7 & day 14 & $\begin{array}{c}\text { Test Start } \\
(\text { day } 0)\end{array}$ & $\begin{array}{l}\text { Test End } \\
\text { (day 14) }\end{array}$ & $\begin{array}{l}\text { Bio mass } \\
\text { change (\%) }\end{array}$ & day 7 & day 14 \\
\hline 1. & $\begin{array}{l}\text { Control (ac- } \\
\text { etone }+ \text { quartz } \\
\text { sand) }\end{array}$ & 0 & 0 & 0 & 393.5 & 360.5 & -8.39 & 0 & 0 \\
\hline 2. & 10 & 0 & 0 & 0 & 367.6 & 339.3 & -7.70 & 0 & 0 \\
\hline 3. & 33 & 0 & 0 & 0 & 384.7 & 341.3 & -11.28 & 0 & 0 \\
\hline 4. & 100 & 0 & 0 & 0 & 359.8 & 296.4 & -17.62 & 0 & 0 \\
\hline 5. & 333 & 0 & 0 & 0 & 331.6 & 233.4 & -29.61 & 0 & 0 \\
\hline 6. & 667 & 10 & 10 & 0 & 362.0 & 209.7 & -42.07 & 0 & 10 \\
\hline 7. & 1000 & 0 & 0 & 0 & 381.8 & 260.3 & -31.82 & 0 & 0 \\
\hline
\end{tabular}

Non-replicated; * Mean weight of live earthworm

soil) from the initial weight. The mean biomass change in the control was $-8.39 \%$ from the initial weight. The details are presented in Table 5.

\section{Behavioural abnormalities}

Earthworms that were lying on the top layer of the soil were observed as a behavioural abnormality. $10 \%$ of the earthworms were noticed on the top layer of the soil on day 0 and day 7 in the concentration $667 \mathrm{mg} / \mathrm{kg}$ dry soil. However, no behavioural abnormality was observed in any other treatments on day 14 . The details are presented in Table 5.

\section{Main test}

\section{Mortality}

After 14 days of exposure to the test item, 2.5\% mortality was observed in the highest test item treatment, $1000 \mathrm{mg} / \mathrm{kg}$ dry soil. The statistical test (Fisher's exact test) revealed that there was no significant difference in mortality in any of the concentrations tested when compared to control. The details are presented in Table 6 .

\section{Behavioural abnormalities}

No behavioural abnormality was observed in any treatments on day 0 and day 7 . However, 2.5\% behavioural abnormality (earthworm lying on the top of the soil) was observed in the concentration $62.5 \mathrm{mg} / \mathrm{kg}$ dry soil on day 14. The details are presented in Table 5.

\section{Biomass}

The biomass changes of the earthworms in the test item treatment ranged between $-26.96 \%$ (1000 $\mathrm{mg} / \mathrm{kg}$ dry soil) and $-4.37 \%$ $(31.25 \mathrm{mg} / \mathrm{kg}$ dry soil) from the initial weight. The mean biomass change in the control was $-0.47 \%$ from the initial weight. The statisti- 
Table 6. Behavioural abnormalities and mortality of the worms from the test item (main experiment)

\begin{tabular}{c|c|c|c|c|cc}
\hline \multirow{2}{*}{ No. } & \multirow{2}{*}{ Treatments (mg/kg dry soil) } & \multicolumn{2}{c|}{ Behavioural abnormalities (\%) } & \multicolumn{2}{c}{ Mortality (\%) } \\
\cline { 3 - 7 } & Day 0 & Day 7 & Day 14 & Day 7 & Day 14 \\
\hline \multirow{2}{*}{$\begin{array}{c}\text { Control } \\
\text { (acetone + quartz sand) }\end{array}$} & 0 & 0 & 0 & 0 & 0 \\
\hline 2. & 31.25 & 0 & 0 & 0 & 0 & 0 \\
\hline 3. & 62.5 & 0 & 0 & 2.5 & 0 & 0 \\
\hline 4. & 125 & 0 & 0 & 0 & 0 & 0 \\
\hline 5. & 250 & 0 & 0 & 0 & 0 & 0 \\
\hline 6. & 500 & 0 & 0 & 0 & 0 & 0 \\
\hline 7. & 1000 & 0 & 0 & 0 & 0 & 2.5 \\
\hline
\end{tabular}

Mean of 4 replications

cal test (Dunnett's test $\alpha=0.05$ ) revealed that there was no significant difference on the biomass change in the concentration $31.25 \mathrm{mg} / \mathrm{kg}$ dry soil when compared to control. However, a significant biomass change was recorded from the concentration of $62.5 \mathrm{mg} / \mathrm{kg}$ dry soil onwards. The details pertaining to the change in biomass of earthworms after 14 days of treatment with the test item are given in Table 7 , and the percentage change in biomass of earthworms after 14 days is presented in Table 8.

Table 7. Earthworm biomass after exposure to the test item (main experiment)

\begin{tabular}{|c|c|c|c|c|c|c|c|c|c|c|c|}
\hline \multirow{3}{*}{ No. } & \multirow{3}{*}{$\begin{array}{l}\text { Treatments } \\
\text { (mg/kg dry } \\
\text { soil) }\end{array}$} & \multicolumn{10}{|c|}{ Mean biomass (mg/worm) } \\
\hline & & \multicolumn{4}{|c|}{ Test start (day 0) } & \multirow{2}{*}{ Mean } & \multicolumn{4}{|c|}{ Test end (day 14) } & \multirow{2}{*}{ Mean } \\
\hline & & RI & RII & RIII & RIV & & RI & RII & RIII & RIV & \\
\hline 1. & $\begin{array}{c}\text { Control } \\
\text { (acetone }+ \\
\text { quartz sand) }\end{array}$ & 406.8 & 387.4 & 378.1 & 396.2 & $\begin{array}{l}392.1 \\
(12.3)\end{array}$ & 406.1 & 404.6 & 367.4 & 383.0 & $\begin{array}{c}390.3 \\
(18.6)\end{array}$ \\
\hline 2. & 31.25 & 355.4 & 406.2 & 370.8 & 395.4 & $\begin{array}{l}382.0 \\
(23.1)\end{array}$ & 352.8 & 382.5 & 358.8 & 365.0 & $\begin{array}{c}364.8 \\
(12.8)\end{array}$ \\
\hline 3. & 62.5 & 384.7 & 372.9 & 378.1 & 381.0 & $\begin{array}{c}379.2 \\
(5.0)\end{array}$ & 342.1 & 355.2 & 364.6 & 347.9 & $\begin{array}{c}352.5 \\
(9.7)\end{array}$ \\
\hline 4. & 125 & 366.0 & 382.1 & 378.4 & 380.0 & $\begin{array}{c}376.6 \\
(7.2)\end{array}$ & 318.1 & 350.8 & 328.0 & 326.6 & $\begin{array}{l}330.9 \\
(14.0)\end{array}$ \\
\hline 5. & 250 & 363.6 & 358.7 & 400.1 & 395.4 & $\begin{array}{l}379.5 \\
(21.3)\end{array}$ & 295.3 & 295.7 & 328.4 & 326.4 & $\begin{array}{l}311.5 \\
(18.4)\end{array}$ \\
\hline 6. & 500 & 376.0 & 365.9 & 382.4 & 387.7 & $\begin{array}{c}378.0 \\
(9.4) \\
\end{array}$ & 303.1 & 285.9 & 301.4 & 305.4 & $\begin{array}{r}299.0 \\
(8.9) \\
\end{array}$ \\
\hline 7. & 1000 & 389.2 & 380.2 & 378.8 & 379.7 & $\begin{array}{c}382.0 \\
(4.9)\end{array}$ & 284.2 & 277.7 & 293.5 & 260.6 & $\begin{array}{l}279.0 \\
(13.9)\end{array}$ \\
\hline
\end{tabular}

$\mathrm{R}$ - Replication; figures in parentheses are standard deviation (SD) 
Table 8. Changes in earthworm biomass - main experiment

\begin{tabular}{|c|c|c|c|c|c|c|}
\hline \multirow{2}{*}{ No. } & \multirow{2}{*}{ Treatments (mg/kg dry soil) } & \multicolumn{4}{|c|}{ Biomass changes $(\%)$} & \multirow{2}{*}{ Mean (\%) } \\
\hline & & RI & RII & RIII & RIV & \\
\hline 1. & $\begin{array}{c}\text { Control } \\
\text { (Acetone }+ \text { Quartz sand) }\end{array}$ & -0.17 & +4.44 & -2.83 & -3.33 & $-0.47(3.6)$ \\
\hline 2. & 31.25 & -0.73 & -5.83 & -3.24 & -7.69 & $-4.37^{\mathrm{ns}},(3.0)$ \\
\hline 3 & 62.5 & -11.07 & -4.75 & -3.57 & -8.69 & $-7.02^{\star}(3.5)$ \\
\hline 4. & 125 & -13.09 & -8.19 & -13.32 & -14.05 & $-12.16^{*}(2.7)$ \\
\hline 5. & 250 & -18.78 & -17.56 & -17.92 & -17.45 & $-17.93^{*}(0.6)$ \\
\hline 6. & 500 & -19.39 & -21.86 & -21.18 & -21.23 & $-20.92^{*}(1.1)$ \\
\hline 7. & 1000 & -26.98 & -26.96 & -22.52 & -31.37 & $-26.96^{\star}(3.6)$ \\
\hline
\end{tabular}

$\mathrm{R}$ - Replication; Figures in the parentheses are Standard Deviation

n.s. - not significant compared to the control

* - significant compared to control (Dunnett's test, $\alpha=0.05$ )

\section{CONCLUSIONS}

It is concluded from the results of this study that the 14-day $\mathrm{LC}_{50}$ of Tricyclozole $75 \% \mathrm{WP}$ was found to be $>1000 \mathrm{mg} / \mathrm{kg}$ dry soil. No observed effect concentration (NOEC) with respect to the biomass and mortality was found at 31.25 and $1000 \mathrm{mg} / \mathrm{kg}$ dry soil, respectively.

Received 5 September 2016 Accepted 1 February 2017

\section{References}

1. Afshar Mohammadian M, Almasi Z, Esmaeili S, Shakib F, Majidi-Shilsar F, Shokrzadeh-Lamuki M. Does pesticides pollution affect rice plants in the southern coastline of the Caspian Sea? Caspian J. Env. Sci. 2015. 13(2): 109-17.

2. Phong KhT, Nhung DTT, Yamazaki K, Takagi $\mathrm{K}$, Watanabe $\mathrm{H}$. Behavior of sprayed tricyclazole in rice paddy lysimeters. Chemosphere. 2009; 74(8): 1085-9.

3. Habibzadeh F, Sorooshzadeh A, Pirdasht H, Modarres Sanavy SAM. Effect of nitrogen compounds and tricyclazole on some bio- chemical and morphological characteristics of waterlogged-canola. IRJABS. 2012; 3: 77-84.

4. Young Deuk Lee, Jung Hun Lee. High-Performance Liquid Chromatographic Determination of Tricyclazole residues in Rice Grain, Rice Straw and Soil. Agr. Chem. Biotechnol. 1998; 41(8): 595-9.

5. Fattahi E, Mosavi Moghaddam M, Khanbabaei RA. The effect of tricyclazole on testosterone changes and testicular structure in mice. J Babol Univ Med Sci. 2015; 17(2): 43-9.

6. Padovani L, Capri E, Padovani C, Puglisi E, Trevisan M. Monitoring tricyclazole residues in rice paddy watersheds. Chemosphere. 2006; 62: 303-14.

7. Qiu XQ, Tong CY, Zhong ZQ, Wang WQ, Zuo YW, Huang Y, Zhang L, Zhang XL, Zhang HX, Li RQ, Wang J, Chen H, Li YY, Wu G, Wang $\mathrm{H}$. An engineered multidomain fungicidal peptide against plant fungal pathogens. Sheng Li Xue Bao. 2013; 65(4): 417-32.

8. Jeong SA, Thapa SP, Park HR, Choi NG, Hur JH. Distribution and Persistence of Tricyaclazole in Agricultural Field Soils. Bull Environ Contam Toxicol. 2012; 89(6): 1181-5.

9. WHO. The WHO recommended classification of pesticides by hazards and guideline to 
classification 2004. World Health Organization, Geneva. p: 24. Available from:http://www. who.int/ipcs/publications/pesticides_ Hazard_ rev_3.pdf.

10. Shahla Yasmin, Doris D’Souza. 2010. Effects of pesticides on the growth and reproduction of earthworm: a review. Applied and Environmental Soil Science. Volume 2010, Article ID 678360, 9 pages.

11. International Organization for Standardisation. Soil quality - effects of pollutants on earthworms (Eisenia fetida) - Part 1: determination of acute toxicity using artificial soil substrate (ISO No. 11268-1). Retrieved from https://www.iso.org/standard/53527.html.

12. International Organization for Standartisation. Soil quality-effects of pollutants on earthworms (Eisenia fetida) - Part 2: determination of effects on reproduction (ISO No. 11268-2). Retrieved from: https://www.iso.org/standard/53528.html.

13. Organization for Economic Co-Operation and Development. OECD guideline for testing of chemicals, Section 2. Test No. 207: Earthworm Acute Toxicity Test. Paris: 1984.

14. Organization for Economic Co-Operation and Development. OECD guideline for testing of chemicals. Test No. 222: Earthworm Reproduction Test (Eisenia fetida/andrei). Paris: 2004.

15. Ma WC, Bodt J. Differences in toxicity of the insecticide chlorpyrifos to six species of earthworms (Oligochaeta, Lumbricidae) in standardized soil tests. Bulletin of Environmental Contamination and Toxicology. 1993; 50(6): 864-70.

16. Kula H. Comparison of laboratory and field testing for the assessment of pesticide side effects on earthworms. Acta Zoologica Fennica. 1995; 196: 338-41.

17. Fitzgerald DG, Warner KA, Lanno RP, Dixon DG. Assessing the effects of modifying factors on pentachlorophenol toxicity to earthworms: applications of body residues. Environmental Toxicology and Chemistry. 1996; 15(2): 2299-304.
18. Bayer DE, Foy CL. Action and fate of adjuvants in soils. In: Adjuvants for Herbicides. Champaign: Weed Science Society of America; 1982. p. 84-92.

\section{Vijayalakshmi Aalaysam, Venkata Reddy Bandugula \\ 75 \% TRICIKLAZOLO MILTELIŲ (WP) ÜMAUS TOKSIŠKUMO POVEIKIS EISENIA FETIDA SLIEKAMS}

\section{Santrauka}

Sliekai yra svarbūs organizmai, išnešiojantys maistines medžiagas dirvožemyje. Palankiausios sąlygos sliekams gyventi yra tuomet, kai dirvožemio $\mathrm{pH}=7,0 \pm 0,5$. Triciklazolo fungicidas yra tiek granulių, tiek miltelių (WP) pavidalo. Dažniausiai viename kilograme produkto yra 750 gramų veikliosios medžiagos (75 \% triciklazolo milteliai). Triciklazolas lengvai tirpsta vandenyje ir yra vidutiniškai toksiškas vandens organizmams; jis stabilus kambario temperatūroje ir lètai yra aplinkos sąlygomis. Šio tyrimo metu sliekai (Eisenia fetida) buvo veikiami $75 \%$ triciklazolo milteliais. Su dešimčia subrendusių sliekų bandymas kartotas keturis kartus - kiekvienas iš jų buvo veikiamas 31,25, 62,5, $125,250,500$ ir $1000 \mathrm{mg} / \mathrm{kg}$ fungicidu sausame dirvožemyje; kontrolinis dirbtinis dirvožemis su acetonu ir kvarciniu smèliu taip pat buvo išbandytas keturis kartus su dešimčia sliekų kiekvieno kartojimo metu. Tyrime buvo vertinama: 1) sliekų elgsena po 0,7 ir 14 poveikio dienų; 2) mirtingumas po 7 ir 14 poveikio dienų; 3 ) sliekų biomase 0 ir 14 dieną. Gauti rezultatai patvirtino $75 \%$ triciklazolo ūmaus toksiškumo poveikị Eisenia foetida sliekams dirbtiniame dirvožemyje.

Raktažodžiai: 75 \% triciklazolo milteliai (WP), Eisenia fetida, mirtingumas, biomase 